\title{
2.4.2. Wsparcie - instrumenty, zobowiązania systemowe, formalne i nieformalne formy
}

DOI: 10.47050/65591838.174-206

Elżbieta Neroj

System oświaty zapewnia realizację prawa każdego obywatela Rzeczypospolitej Polskiej do kształcenia się oraz prawa dzieci i młodzieży do wychowania i opieki, odpowiednio do wieku i osiągniętego rozwoju. Istnieją również regulacje prawne dotyczące dostosowania treści, metod i organizacji nauczania do możliwości psychofizycznych uczniów, a także związane z możliwością korzystania z pomocy psychologiczno-pedagogicznej i specjalnych form pracy dydaktycznej ${ }^{1}$. Wśród podstawowych zadań systemu oświaty ustawodawca określił zapewnianie warunków rozwoju zainteresowań i uzdolnień uczniów oraz opiekę nad uczniami niepełnosprawnymi, szczególnie uzdolnionymi oraz pozostającymi w trudnej sytuacji materialnej i życiowej.

Założenia te są realizowane poprzez określenie w przepisach prawa zróżnicowanych instrumentów wsparcia. Przez pojęcie "instrumenty wsparcia" rozumie się w niniejszym podrozdziale wszelkie zasoby, działania i strategie, których zastosowanie ma wspierać rozwój uczniów, pomagać im w nabywaniu wiedzy i umiejętności określonych w podstawach programowych, stwarzać warunki rozwijania zainteresowań oraz aktywnego i pełnego uczestnictwa w środowisku społecznym (Schalock i in. 2010, s. 18). Dla ułatwienia odbioru w tekście stosuje się określenie „uczeń”, które obejmuje również dzieci w wieku przedszkolnym, jeśli opisywany instrument wsparcia stosowany jest na tym etapie edukacyjnym. 
Różne możliwości wsparcia uregulowane zostały w wielu dokumentach prawnych, zarówno na poziomie ustawowym², jak i w aktach wykonawczych - nie tylko tych, które wprost odnoszą się do obszaru kształcenia uczniów ze specjalnymi potrzebami edukacyjnymi. Wymaga to od dyrektorów jednostek systemu oświaty, nauczycieli i specjalistów planujących i realizujących działania wspierające dobrej znajomości przepisów i umiejętnego wykorzystywania wskazanych w nich możliwości w celu określenia takiego planu działań, który odpowiada potrzebom konkretnego ucznia. Rozproszenie unormowań dotyczących instrumentów wsparcia, nierzadko niespójność terminologii z przepisami regulującymi udzielanie wsparcia $w$ innych resortach ${ }^{3}$ oraz brak doprecyzowania niektórych pojęć ${ }^{4}$ - te czynniki utrudniają stosowanie prawa. Uproszczenie, uspójnienie i doprecyzowanie przepisów przyczyniłoby się do poprawy sytuacji, szczególnie rodziców, dla których znajomość regulacji prawnych i wynikających z nich możliwości w zakresie wsparcia ich dziecka jest bardzo ważna. Dzięki temu mogą oni aktywnie i świadomie włączać się w planowanie wsparcia i egzekwować realizację zadań przez przedszkole, szkołę czy placówkę. We wprowadzanych w ostatnich latach zmianach przepisów regulujących kształcenie uczniów ze specjalnymi potrzebami edukacyjnymi szczególnie podkreśla się rolę rodziców jako partnerów i współuczestników procesu oceny potrzeb rozwojowych i edukacyjnych ucznia, planowania zakresu i form wsparcia, monitorowania postępów oraz oceny efektywności udzielanego wsparcia. Rodzic ${ }^{5}$ może zainicjować udzielanie pomocy psychologiczno-pedagogicznej ${ }^{6}$. Ustawa Prawo oświatowe oraz Ustawa z dnia 7 września 1991 r. o systemie oświaty (Dz.U. z 2018 r. poz. 1457 z późn. zm.).

3 Przykładem są różnice w określaniu niepełnosprawności w resorcie oświaty oraz w systemie zabezpieczenia społecznego.

Na przykład pojęć: „uczeń słabosłyszący”, „słabowidzący” lub „zagrożony niedostosowaniem społecznym".

Pojęcie „rodzice" obejmuje również prawnych opiekunów dziecka oraz osoby (podmioty) sprawujące nad nim pieczę zastępczą.

Par. 5 pkt 2 Rozporządzenia Ministra Edukacji Narodowej z dnia 9 sierpnia 2017 r. w sprawie zasad organizacji i udzielania pomocy psychologiczno-pedagogicznej w publicznych przedszkolach, szkołach i placówkach (Dz.U. poz. 1591 z późn. zm.); par. 6 pkt 2 Rozporządzenia Ministra Edukacji Narodowej z dnia 30 kwietnia 2013 r. w sprawie zasad udzielania i organizacji pomocy psychologiczno-pedagogicznej w publicznych szkołach i placówkach (Dz.U. poz. 532 z późn. zm.). 
Ma także prawo uczestniczyć w opracowaniu i modyfikacji indywidualnego programu edukacyjno-terapeutycznego dla swojego dziecka oraz brać udział w wielospecjalistycznej ocenie jego funkcjonowania ${ }^{7}$. To rodzic lub pełnoletni uczeń zgłaszają się do poradni psychologiczno-pedagogicznej i wnioskują o wydanie opinii lub orzeczenia9. Również do nich należy decyzja o formie kształcenia specjalnego ${ }^{10}$, którą zobowiązany jest zapewnić organ samorządu terytorialnego odpowiedzialny za prowadzenie danego rodzaju szkoły lub placówki.

W dalszej części zostanie wskazana rola rodziców i ich prawa w odniesieniu do poszczególnych instrumentów wsparcia, aby zachęcić ich do wykorzystania istniejących możliwości współpracy z przedszkolem czy szkołą. Jak pokazują badania, znaczny odsetek rodziców nie bierze udziału w kształceniu własnych dzieci (Kubicki i in. 2015, s. 120). Włączenie ich w ten proces pozwoli możliwie najlepiej wykorzystać czas edukacji do przygotowania dzieci do samodzielnego, satysfakcjonującego życia w dorosłości. Nauczyciele i dyrektorzy szkół zobowiązani są do zapewnienia rodzicom realnych warunków realizacji ich praw. Nie tylko obowiązek powinien być jednak powodem podejmowania takich działań. Dobrze zorganizowana współpraca z rodzicami przekłada się pozytywnie na rozwój dziecka, warunki i efekty pracy nauczycieli i dyrektora szkoły oraz klimat placówki edukacyjnej. Relacje między nauczycielami i rodzicami mogą być czynnikiem wpływającym na jakość nauczania, budowanie jednolitej strategii edukacyjnej w szkole i w rodzinie, kształtowanie postaw obywatelskich (Hernik, Malinowska 2015, s. 8). Nadal jednak istnieją bariery, które utrudniają

Par. 6 ust. 11 Rozporządzenia Ministra Edukacji Narodowej z dnia 9 sierpnia 2017 r. w sprawie warunków organizowania kształcenia, wychowania i opieki dla dzieci i młodzieży niepełnosprawnych, niedostosowanych społecznie i zagrożonych niedostosowaniem społecznym (Dz.U. poz. 1578 z późn. zm.); par. 6 ust. 10 Rozporządzenia Ministra Edukacji Narodowej z dnia 24 lipca 2015 r. w sprawie warunków organizowania kształcenia, wychowania i opieki dla dzieci i młodzieży niepełnosprawnych, niedostosowanych społecznie i zagrożonych niedostosowaniem społecznym (Dz.U. poz. 1113 z późn. zm.).

Par. 5 ust. 1 Rozporządzenia Ministra Edukacji Narodowej z dnia 1 lutego 2013 r. w sprawie szczegółowych zasad działania publicznych poradni psychologiczno-pedagogicznych (Dz.U. poz. 199 oraz z 2017 r. poz. 1647).

Par. 5 ust. 2 Rozporządzenia Ministra Edukacji Narodowej z dnia 7 września 2017 r. w sprawie wydawania orzeczeń i opinii działających w publicznych poradniach psychologiczno-pedagogicznych (Dz.U. poz. 1743). 
prowadzenie tej współpracy w praktyce (Lewicka-Zelent, Chimicz 2018, s. 98-100).

Przepisy prawne zobowiązują publiczną szkołę podstawową do przyjęcia każdego dziecka zamieszkałego w jej obwodzie`11. Zarówno szkoła obwodowa, jak i ta, do której uczeń został przyjęty w toku rekrutacji, nie może odmówić przyjęcia kandydata posiadającego orzeczenie o potrzebie kształcenia specjalnego, argumentując, że nie posiada warunków czy możliwości zapewnienia mu wsparcia. Przepisy wskazują wprost, że szkoła jest zobowiązana do realizacji zaleceń zawartych w orzeczeniu ${ }^{12}$ oraz do zapewnienia uczniowi - tak jak w przypadku jego rówieśników - pomocy psychologiczno-pedagogicznej adekwatnej do jego potrzeb ${ }^{13}$. Środki na ten cel przekazywane są z budżetu państwa w części oświatowej subwencji ogólnej ${ }^{14}$.

\section{Planowanie wsparcia}

Plan oddziaływań wspierających ucznia zawsze powinien być unikalny, nie ma bowiem dwóch identycznie funkcjonujących osób. Ten sam rodzaj niepełnosprawności czy to samo rozpoznanie medyczne może przejawiać się w różny sposób i w różnym nasileniu u poszczególnych uczniów. Każde dziecko ma niepowtarzalny zasób zdolności i mocnych stron, a środowisko (szkoła, dom, grupa rówieśnicza) w różny sposób wpływa na jego rozwój i codzienne funkcjonowanie. Holistyczne postrzeganie potrzeb każdego dziecka i planowanie pracy oparte na założeniu, że każde z nich może czynić postępy, stanowi

Tamże, art. 130 ust. 2.

12 Zgodnie z art. 68 ust. 1 pkt 10 ww. ustawy odpowiada za to dyrektor szkoły. Zobowiązanie to dotyczy również dyrektora przedszkola, jak i placówki. Regulacje w tym zakresie zawarte są także w przepisach rozporządzeń Ministra Edukacji Narodowej w sprawie warunków organizowania kształcenia, wychowania i opieki dla dzieci i młodzieży niepełnosprawnych, niedostosowanych społecznie i zagrożonych niedostosowaniem społecznym z dnia 24 lipca 2015 r. (par. 5) oraz z dnia 9 sierpnia 2017 r. (par. 5).

Zgodnie z art. 1 pkt 5 ustawy Prawo oświatowe oraz z przepisami w sprawie zasad organizacji i udzielania pomocy psychologiczno-pedagogicznej w publicznych przedszkolach, szkołach i placówkach.

Zgodnie z art. 8 Ustawy z dnia 27 października 2017 r. o finansowaniu zadań oświatowych (Dz.U. poz. 2203 z późn. zm.) w danym roku budżetowym na realizację zadań związanych z organizacją kształcenia specjalnego oraz zajęć rewalidacyjno-wychowawczych jednostka samorządu terytorialnego przeznacza środki w wysokości nie mniejszej niż kwota przewidziana w części oświatowej subwencji ogólnej na ten cel. 
realizację w praktyce idei indywidualizacji15. Jest ona obecnie coraz częściej określana jako "personalizacja” procesu uczenia się, co sprzyja podkreśleniu jego osobistego charakteru w rozwoju ucznia, będącego jednocześnie podmiotem oddziaływań, jak i ich współkreatorem. Często niesłusznie indywidualizacja utożsamiana jest z postrzeganiem indywidualnych oddziaływań wobec dziecka jako bardziej skutecznych od uczenia się w grupie i dlatego najlepiej wspierających jego rozwój. Tymczasem nie tylko rozwijanie kompetencji społeczno-emocjonalnych dziecka nie może odbywać się w oderwaniu od grupy rówieśniczej - uczenie się w grupie zróżnicowanej pod względem możliwości i potrzeb edukacyjnych sprzyja osiągnięciom akademickim i wspiera rozwój społeczny wszystkich uczniów, nie tylko tych, u których rozpoznano specjalne potrzeby edukacyjne (INCLUD-ED 2012, [za: Europejska Agencja 2016, s. 59]).

Im wyższy poziom edukacyjny, na którym oferuje się instrument wsparcia, tym większą liczbę podmiotów obejmuje jego oddziaływanie. Wprowadzenie udogodnień, które służą uczniowi ze specjalnymi potrzebami edukacyjnymi, może także poprawić warunki uczenia się jego kolegów. Dlatego w przypadku wystąpienia trudności u danego ucznia konieczne jest rozważenie, czy bariera, która utrudnia jego funkcjonowanie, nie występuje na poziomie szkoły lub klasy, a w związku $z$ tym, czy jej usunięcie nie poprawi warunków uczenia się również jego kolegów i koleżanek.

Uczeń jest zanurzony w swoistym ekosystemie struktur i procesów zachodzących na różnych poziomach, które mają wpływ na jego rozwój, naukę i osiągnięcia (Europejska Agencja 2017a, s. 11). Mimo że podmiotem oddziaływań zawsze będzie uczeń, a ich celem będzie zapewnienie mu optymalnych warunków rozwoju i nauki, niezbędne są także działania skierowane do środowiska wychowania i nauczania (przedszkola, szkoły, klasy, grupy rówieśniczej, rodziny, do społeczności lokalnej), a także na poziomie krajowym, na którym zapewniane są ramy organizacyjne i standardy działania oraz - co równie ważne - budowany jest klimat społeczny sprzyjający edukacji włączającej. Takie pojmowanie wsparcia w procesie kształcenia i wychowania opiera się na zrozumieniu, że specjalne potrzeby edukacyjne powstają w wyniku rozbieżności 
między osobistymi kompetencjami ucznia a wymaganiami środowiska edukacyjnego i wychowawczego, w jakim funkcjonuje (Schalock i in. 2012 [za: Hagiwara i in. 2019, s. 4]). Zastosowanie instrumentów wsparcia służy niwelowaniu tych rozbieżności poprzez zapewnienie uczniom jak najszerszego dostępu do treści nauczania i umożliwienie czynienia postępów na miarę ich możliwości. Dzieci z bardziej złożonymi potrzebami, wymagające intensywniejszego wsparcia, mogą również efektywnie uczyć się zgodnie z podstawą programową realizowaną w szkole ogólnodostępnej, gdy zapewni się im odpowiednią pomoc dydaktyczną ${ }^{16}$, działania wspomagające uczestnictwo oraz dostosowania programowe (Hagiwara i in. 2019, s. 5).

W przepisach prawa oświatowego przewidziano instrumenty wsparcia na różnych poziomach oddziaływań - społeczności lokalnej, przedszkola, szkoły lub placówki, klasy, grupy wychowawczej, nauczycieli i specjalistów, rodziców, a także skierowane bezpośrednio do dziecka lub ucznia ${ }^{17}$.

Rysunek 1. Poziomy stosowania instrumentów wsparcia

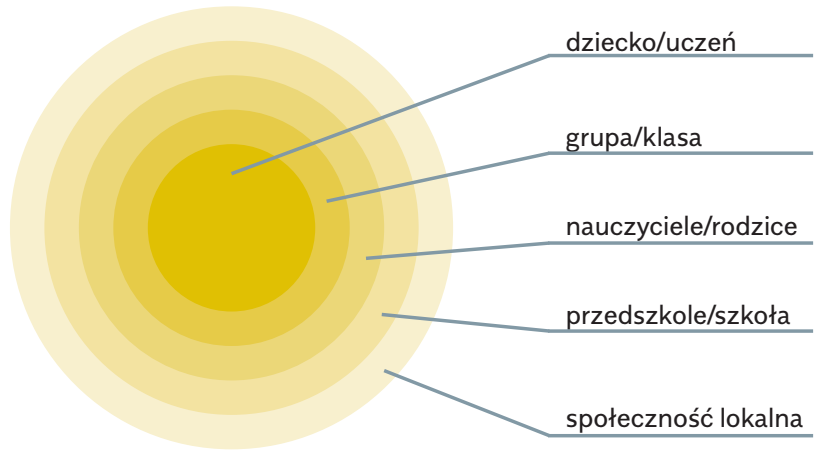

Źródło: Opracowanie własne.

Na przykład przez dostosowanie do potrzeb ucznia formy i sposobu przekazu wyjaśnień i poleceń, zastosowanie technologii wspomagających, odpowiedni dobór materiałów dydaktycznych. 
Zaplanowanie rodzaju instrumentów wsparcia, jakie należałoby zastosować do rozwiązania konkretnego problemu dotyczącego funkcjonowania ucznia, musi być poprzedzone określeniem celów, które mają zostać osiągnięte (Petty 2013, s. 381-392), jak również wskaźników, które pozwolą ocenić postępy tego procesu. Jeśli cele oddziaływań będą jasno zdefiniowane (precyzyjne), mierzalne, osiągalne, istotne dla poprawy funkcjonowania dziecka oraz określone w czasie (czyli zaprojektowane zgodnie z zasadą SMART ${ }^{18}$ ) - łatwiej je będzie osiągnąć.

Każdy uczeń może czynić postępy i rozwijać się. W sytuacji, gdy napotyka na trudności w rozwoju czy nauce, rolą nauczyciela jest zastosowanie odpowiednich metod pracy, które pomogą wich przezwyciężeniu. Nie może on być w tym zadaniu osamotniony - powinien współpracować z innymi nauczycielami, specjalistami (w tym także spoza przedszkola/szkoły), rodzicami i samymi uczniami. Możliwości w tym zakresie są określone w przepisach, występuje jednak często problem z ich stosowaniem w praktyce. Urzeczywistnianiu tej współpracy sprzyja rozwijanie kompetencji przywódczych dyrektorów szkół i komunikacyjnych nauczycieli, jak również ograniczanie biurokracji (Chmielińska, Modrzejewska-Świgulska 2018, s. 12-13).

Jednym z ważnych obszarów pracy przedszkola i szkoły jest efektywne korzystanie ze zgromadzonych przez placówkę i dostępnych w środowisku lokalnym zasobów w taki sposób, by skutecznie wspierać wszystkie dzieci w rozwoju oraz nabywaniu wiedzy i umiejętności na możliwie najwyższym poziomie, a także wzmacniać ich autentyczne zaangażowanie $w$ proces uczenia się.

Aby powyższe założenia mogły być realizowane w codziennej praktyce, konieczne jest wzmacnianie potencjału przedszkoli i szkół w: zapewnianiu wsparcia jak najszybciej po rozpoznaniu takiej potrzeby, stosowaniu innowacyjnych metod nauczania w odpowiedzi na zróżnicowane potrzeby uczniów, jak również umożliwianiu realizacji spersonalizowanych ścieżek kształcenia przez uczniów (Europejska Agencja 2019, s. 9). osiągnięcia. Nazwa jest akronimem złożonym z pierwszych liter angielskich słów: S - Specific (skonkretyzowany), M - Measurable (mierzalny), A - Achievable (osiągalny), R - Relevant (istotny), T - Time-bound (określony w czasie) (za: Walczak 2014, s. 110). 


\section{Instrumenty wsparcia przeznaczone dla przedszkola, szkoły i placówki jako instytucji oraz kadry}

W realizacji zadań dydaktycznych, wychowawczych i opiekuńczych przedszkola, szkoły i placówki mogą korzystać ze wsparcia publicznych poradni psychologiczno-pedagogicznych, placówek doskonalenia nauczycieli oraz bibliotek pedagogicznych. $\mathrm{O}$ tego rodzaju pomoc zwraca się przede wszystkim zainteresowana placówka, ale wsparcie może zostać uruchomione również $w$ efekcie procesu diagnozy dziecka lub ucznia w poradni psychologiczno-pedagogicznej19 lub na wniosek rodzica dziecka niepełnosprawnego bądź pełnoletniego ucznia ${ }^{20}$.

Publiczna poradnia psychologiczno-pedagogiczna na terenie określonym przez jej organ prowadzący oferuje pomoc dzieciom od ich urodzenia, uczniom, ich rodzicom i nauczycielom, a także wspomaga przedszkola, szkoły i placówki jako organizacje. Zakres działań poradni jest szeroki i obejmuje zwłaszcza:

$\rightarrow$ wsparcie merytoryczne i pomoc dla nauczycieli, opiekunów grup wychowawczych i specjalistów w rozpoznawaniu potrzeb i możliwości psychofizycznych dzieci (uczniów) oraz planowaniu i realizacji określonych zadań (m.in. w zakresie doradztwa edukacyjno-zawodowego, pomocy psychologiczno-pedagogicznej, rozwijania zainteresowań i uzdolnień uczniów);

$\rightarrow$ współpracę $\mathbf{w}$ opracowywaniu i realizowaniu indywidualnych programów dla uczniów (edukacyjno-terapeutycznych oraz rewalidacyjno-wychowawczych);

$\rightarrow$ współpracę w określeniu niezbędnych do nauki dzieci i uczniów niepełnosprawnych warunków, sprzętu specjalistycznego i środków dydaktycznych, w tym wykorzystujących technologie informacyjno-komunikacyjne (taką współpracą może także zainicjować rodzic lub pełnoletni uczeń) ${ }^{21}$;

$\rightarrow$ organizowanie i prowadzenie tzw. kompleksowego wspomagania przedszkoli, szkół i placówek w zakresie realizacji zadań dydaktycznych, wychowawczych i opiekuńczych. poradni psychologiczno-pedagogicznych. 
Przepisy umożliwiają dostosowanie oferty poradni do lokalnych potrzeb. Formy wsparcia oferowane przez te placówki to: porady, konsultacje, udział w spotkaniach nauczycieli, opiekunów grup wychowawczych i specjalistów oraz w zebraniach rad pedagogicznych, warsztaty, grupy wsparcia, wykłady, prelekcje, mediacje, interwencje kryzysowe, działania informacyjno-szkoleniowe, a także organizowanie i prowadzenie sieci współpracy i samokształcenia.

Wspomaganie w realizacji zadań dydaktycznych, wychowawczych i opiekuńczych polega na zaplanowaniu i przeprowadzeniu działań mających na celu poprawę jakości pracy przedszkola, szkoły lub placówki. Odbywa się ono w zakresie, który wynika z rozpoznania potrzeb dzieci i młodzieży oraz z indywidualizacji procesu nauczania i wychowania, analizy wyników i wniosków z nadzoru pedagogicznego oraz wyników egzaminów zewnętrznych, a także z innych potrzeb wskazanych przez przedszkole, szkołę lub placówkę. Obejmuje pomoc w diagnozowaniu problemów, ustalenie sposobów działania prowadzących do ich zniwelowania, zaplanowanie form wspomagania i ich realizację, a także wspólną ocenę efektów i opracowanie wniosków po zakończeniu procesu wspomagania. Jest to jedno z obowiązkowych zadań nie tylko publicznych poradni psychologiczno-pedagogicznych, ale również publicznych placówek doskonalenia nauczycieli oraz bibliotek pedagogicznych.

Obok realizowania różnych form doskonalenia zawodowego nauczycieli oraz dyrektorów przedszkoli, szkół i placówek systemu oświaty, publiczne placówki doskonalenia nauczycieli organizują i prowadzą sieci współpracy i samokształcenia dla nauczycieli oraz dyrektorów udzielają konsultacji i upowszechniają przykłady dobrej praktyki22.

Publiczne biblioteki pedagogiczne wspierają proces kształcenia i doskonalenia nauczycieli oraz działalność szkół i placówek poprzez zapewnianie dostępu do zasobów informacyjnych (m.in. dotyczących problematyki związanej z udzielaniem dzieciom i młodzieży oraz rodzicom i nauczycielom pomocy psychologiczno-pedagogicznej), prowadzenie działalności informacyjnej i bibliograficznej oraz inspirowanie, a także promowanie edukacji czytelniczej i medialnej23. Biblioteki mogą doskonalenia nauczycieli (Dz.U. poz. 1045). 
również prowadzić działalność wydawniczą, edukacyjną i kulturalną, (np. w ramach otwartych zajęć edukacyjnych, lekcji bibliotecznych i spotkań autorskich).

Wsparcie szkół w diagnozowaniu i rozwiązywaniu problemów dydaktyczno-wychowawczych uczniów objętych kształceniem specjalnym zapewniają również placówki specjalne: młodzieżowe ośrodki wychowawcze, młodzieżowe ośrodki socjoterapii oraz specjalne ośrodki szkolno-wychowawcze ${ }^{24}$.

Szkoła nie powinna biernie oczekiwać na zainteresowanie zewnętrznych podmiotów jej problemami (co najczęściej występuje w sytuacji pojawienia się poważnych problemów z funkcjonowaniem uczniów), a raczej aktywnie poszukiwać sojuszników do realizacji swoich zadań (Ainscow i in. 2012, cytowane w: Europejska Agencja 2016b). Proces rozwoju szkoły jako organizacji uczącej się obejmuje ciągłe doskonalenie metod własnej pracy w odpowiedzi na potrzeby uczniów. Celem powinno być rozszerzanie oferty działań profilaktycznych i prewencyjnych, zamiast koncentrowania się przede wszystkim na interwencji w sytuacji wystąpienia problemów oraz kompensowaniu deficytów (Europejska Agencja 2019, s. 6).

Społeczność lokalna stanowi ogromny zasób dla placówek edukacyjnych. Możliwości uzyskania nieformalnego wsparcia ze strony różnych podmiotów działających lokalnie są praktycznie nieograniczone. Jak pokazuje praktyka, najczęściej jest to wsparcie zapewniane przez rodziców, lokalnych przedsiębiorców oraz służby publiczne, w tym policję i straż pożarną, jak również organizacje pozarządowe działające na rzecz dzieci i młodzieży oraz rodziny. W wielu miejscach w Polsce z sukcesami działają inicjowane przez samorządy koalicje, które wspierają nie tylko rozwój edukacji włączającej, ale także służą budowaniu dostępnego, włączającego środowiska lokalnego25. w sprawie publicznych placówek oświatowo-wychowawczych, młodzieżowych ośrodków wychowawczych, młodzieżowych ośrodków socjoterapii, specjalnych ośrodków szkolno-wychowawczych, specjalnych ośrodków wychowawczych, ośrodków rewalidacyjno-wychowawczych oraz placówek zapewniających opiekę i wychowanie uczniom w okresie pobierania nauki poza miejscem stałego zamieszkania (Dz.U. poz. 1606 oraz z 2017 r. poz. 1628). 


\section{Instrumenty wsparcia związane z organizacją przedszkola, szkoły lub placówki}

Potrzeby rozwojowe i edukacyjne oraz możliwości psychofizyczne wszystkich uczniów powinny być uwzględnione na etapie planowania pracy w danym roku szkolnym. Należy zadbać o:

1. Zaplanowanie w arkuszu organizacji przedszkola, szkoły, placówki ${ }^{26}$ odpowiednio do rozpoznanych potrzeb edukacyjnych i rozwojowych dzieci i uczniów:

- kadry przygotowanej do ich zaspokojenia: nauczycieli, wychowawców, specjalistów oraz personelu niepedagogicznego ${ }^{27}$,

- liczby godzin zajęć rewalidacyjnych (dla uczniów niepełnosprawnych, posiadających orzeczenie o potrzebie kształcenia specjalnego) ${ }^{28}$, resocjalizacyjnych (dla uczniów niedostosowa-

Par. 17 Rozporządzenia Ministra Edukacji Narodowej z dnia 17 marca 2017 r. w sprawie szczegółowej organizacji publicznych szkół i publicznych przedszkoli (Dz.U. poz. 649 oraz z 2018 r. poz. 691); par. 73 rozporządzenia w sprawie publicznych placówek oświatowo-wychowawczych, młodzieżowych ośrodków wychowawczych, młodzieżowych ośrodków socjoterapii, specjalnych ośrodków szkolno-wychowawczych, specjalnych ośrodków wychowawczych, ośrodków rewalidacyjno-wychowawczych oraz placówek zapewniających opiekę i wychowanie uczniom w okresie pobierania nauki poza miejscem stałego zamieszkania.

Wynika to z obowiązku zapewnienia pomocy psychologiczno-pedagogicznej zgodnie z art. 1 pkt 5 ustawy Prawo oświatowe, par. 1 i 4 ust. 1 i 2 rozporządzenia Ministra Edukacji Narodowej z dnia 9 sierpnia 2017 r. w sprawie zasad organizacji i udzielania pomocy psychologiczno-pedagogicznej w publicznych przedszkolach, szkołach i placówkach, par. 1 i 5 ust. 2 oraz rozporządzeń Ministra Edukacji Narodowej w sprawie warunków organizowania kształcenia, wychowania i opieki dla dzieci i młodzieży niepełnosprawnych, niedostosowanych społecznie i zagrożonych niedostosowaniem społecznym: z dnia 9 sierpnia 2017 r. (par. 7) oraz z dnia 24 lipca 2015 r. (par. 7).

Rozporządzenia Ministra Edukacji Narodowej w sprawie warunków organizowania kształcenia, wychowania i opieki dla dzieci i młodzieży niepełnosprawnych, niedostosowanych społecznie i zagrożonych niedostosowaniem społecznym: z dnia 9 sierpnia 2017 r. (par. 6 ust. 1 pkt 5) oraz z dnia 24 lipca 2015 r. (par. 6 ust. 1 pkt 5). Minimalna tygodniowa liczba takich zajęć jest określona w przepisach w sprawie ramowych planów nauczania odpowiednio na ucznia (szkoły/ oddziały ogólnodostępne i integracyjne) oraz na oddział (szkoły specjalne, oddziały specjalne w szkołach ogólnodostępnych). Rzeczywista liczba godzin zajęć oraz ich forma (indywidualna lub grupowa) powinny zawsze wynikać z potrzeb poszczególnych uczniów. Dotyczy to także szkół i oddziałów specjalnych: uczeń realizuje taką liczbę i taki rodzaj zajęć rewalidacyjnych, jakie wynikają z jego indywidualnego programu edukacjo-terapeutycznego. Brak określenia w przepisach minimalnej liczby godzin zajęć rewalidacyjnych w przedszkolu nie oznacza, że nie ma obowiązku realizacji tych zajęć - przeciwnie, wymóg taki wskazano zarówno w ustawie Prawo oświatowe (art. 1 oraz art. 127 ust. 4), jak i w przepisach wydanych na podstawie art. 127 ust. 19 pkt 2 tej ustawy. 
nych społecznie) ${ }^{29}$ oraz socjoterapeutycznych (dla uczniów zagrożonych niedostosowaniem społecznym) ${ }^{30}$,

- liczby godzin zajęć z zakresu pomocy psychologiczno-pedagogicznej oraz innych, wspomagających proces kształcenia, realizowanych w szczególności przez pedagoga, psychologa, logopedę i innych nauczycieli;

2. Ustalenie rodzaju i liczebności oddziałów (ogólnodostępnych, integracyjnych, specjalnych, klas terapeutycznych ${ }^{31}$, przygotowawczych ${ }^{32}$ );

3. Opracowanie programu wychowawczo-profilaktycznego ${ }^{33}$;

4. Zaplanowanie działań w zakresie doskonalenia nauczycieli34;

5. Opracowanie planu nadzoru pedagogicznego ${ }^{35}$;

6. Zaplanowanie działań w zakresie doradztwa zawodowego ${ }^{36}$. wychowania i opieki dla dzieci i młodzieży niepełnosprawnych, niedostosowanych społecznie i zagrożonych niedostosowaniem społecznym: z dnia 9 sierpnia 2017 r. (par. 6 ust. 1 pkt 5) oraz z dnia 24 lipca 2015 r. (par. 6 ust. 1 pkt 5). Tamże.

Par. 13 rozporządzenia Ministra Edukacji Narodowej z dnia 9 sierpnia 2017 r. w sprawie zasad organizacji i udzielania pomocy psychologiczno-pedagogicznej w publicznych przedszkolach, szkołach i placówkach; par. 8 rozporządzenia Ministra Edukacji Narodowej z dnia 30 kwietnia 2013 r. w sprawie zasad udzielania i organizacji pomocy psychologiczno-pedagogicznej w publicznych szkołach i placówkach.

Art. 165 ust. 11-13 ustawy Prawo oświatowe oraz par. 16 Rozporządzenia Ministra Edukacji Narodowej z dnia 23 sierpnia 2017 r. w sprawie kształcenia osób niebędących obywatelami polskimi oraz osób będących obywatelami polskimi, które pobierały naukę w szkołach funkcjonujących w systemach oświaty innych państw (Dz.U. poz. 1655).

Zgodnie z art. 26 ustawy Prawo oświatowe. Pomocne materiały do realizacji tych zadań znajdują się na stronie programu „Bezpieczna szkoła” (bezpiecznaszkola.men.gov.pl).

Art. 7 ust. 2 pkt 4 Ustawy z dnia 26 stycznia 1982 r. Karta Nauczyciela (Dz.U. z 2018 r. poz. 967 z późn. zm.) oraz par. 4 Rozporządzenia Ministra Edukacji Narodowej z dnia 18 stycznia 2019 r. w sprawie dofinansowania doskonalenia zawodowego nauczycieli (Dz.U. poz. 136).

Par. 23 ust. 1 Rozporządzenia Ministra Edukacji Narodowej z dnia 25 sierpnia 2017 r. w sprawie nadzoru pedagogicznego (Dz.U. poz. 1658). 


\section{Instrumenty wsparcia skierowane do klasy lub do grupy wychowawczej}

Wśród instrumentów wsparcia skierowanych do oddziału przedszkolnego lub klasowego można wyróżnić:

1. Możliwość dostosowania liczebności grupy wychowawczej lub klasy37;

2. Ustalenie tygodniowego rozkładu zajęć ( $w$ tym godziny ich rozpoczęcia i zakończenia w poszczególnych dniach, z uwzględnieniem specyficznych potrzeb uczniów, wynikających np. z przewlekłej choroby);

3. Zapewnienie dodatkowej kadry, zwłaszcza w przypadku, gdy do oddziału uczęszczają uczniowie objęci kształceniem specjalnym, a także określenie zakresu czynności poszczególnych pracowników ${ }^{38}$. Mogą to być: nauczyciele posiadający kwalifikacje w zakresie pedagogiki specjalnej ${ }^{39}$, specjaliści, pomoc nauczyciela;

4. Okresowe lub roczne zwiększenie liczby godzin wybranych obowiązkowych zajęć edukacyjnych ${ }^{40}$;

5. Realizację dodatkowych zajęć edukacyjnych ${ }^{41}$;

6. Prowadzenie zajęć z języka migowego ${ }^{42}$; szkół i publicznych przedszkoli. Należy zauważyć, że określają one górną, a nie dolną granicę liczebności oddziałów.

Zgodnie z przepisami rozporządzeń Ministra Edukacji Narodowej w sprawie warunków organizowania kształcenia, wychowania i opieki dla dzieci i młodzieży niepełnosprawnych, niedostosowanych społecznie i zagrożonych niedostosowaniem społecznym: z dnia 9 sierpnia 2017 r. (par. 7) oraz z dnia 24 lipca 2015 r. (par. 7). Obowiązkowo w przypadku oddziału integracyjnego, opcjonalnie - oddziału ogólnodostępnego.

Na podstawie par. 3 ust. 1 pkt 1 Rozporządzenia Ministra Edukacji Narodowej z dnia 28 marca 2017 r. w sprawie ramowych planów nauczania dla publicznych szkół (Dz.U. poz. 703).

Na podstawie par. 3 ust. 1 pkt 2 ww. rozporządzenia. Do dodatkowych zajęć edukacyjnych zalicza się: te z języka obcego nowożytnego innego niż nauczany w ramach obowiązkowych zajęć edukacyjnych oraz zajęcia, dla których nie została ustalona podstawa programowa, lecz program nauczania tych zajęć został włączony do szkolnego zestawu programów nauczania (art. 109 ust 1 pkt 2 ustawy Prawo oświatowe). 
7. Naukę geografii państwa, z którego obszarem kulturowym utożsamia się mniejszość narodowa ${ }^{43}$;

8. Odpowiednie do potrzeb uczniów wyposażenie klasy (np. zapewnienie ławki dostosowanej do ucznia poruszającego się na wózku inwalidzkim, kącik do wypoczynku), sprzęt specjalistyczny (np. pętla indukcyjna, linijka brajlowska lub komputer z oprogramowaniem dla osób niewidomych), pomoce dydaktyczne $^{44}$ (np. tablica interaktywna, materiały w języku Braille'a lub polskim języku migowym);

9. Dostosowanie organizacji pracy w grupie/na lekcji (np. aranżacja klasy - ustawienie ławek, krzeseł);

10. Dobór odpowiednich metod pracy.

\section{Instrumenty wsparcia kierowane do rodziców uczniów}

Przedszkola, szkoły i placówki zobowiązane są do zapewniania pomocy psychologiczno-pedagogicznej rodzicom. Pomoc ta polega na wspieraniu ich w rozwiązywaniu problemów wychowawczych i dydaktycznych oraz rozwijaniu umiejętności wychowawczych rodziców ${ }^{45}$. Rodzice mogą skorzystać również z usług poradni psychologiczno-pedagogicznych (publicznych i niepublicznych). Poradnie publiczne oferują pomoc w rozpoznawaniu potrzeb dzieci i młodzieży oraz w rozwiązywaniu problemów edukacyjnych i wychowawczych, wsparcie terapeutyczne (np. terapię rodziny), interwencję kryzysową, mediację. Organizują także grupy wsparcia, warsztaty, prelekcje, udzielają porad i konsultacji. Usługi publicznych poradni są nieodpłatne, a wsparcie odbywa się zawsze na wniosek rodzica.

Na podstawie par. 3 ust. 1 pkt 4 ww. rozporządzenia. Zgodnie z art. 2 ust. 2 Ustawy z dnia 6 stycznia 2005 r. o mniejszościach narodowych i etnicznych oraz o języku regionalnym (Dz.U. z 2017 r. poz. 823) w Polsce status mniejszości posiadają osoby narodowości: białoruskiej, czeskiej, litewskiej, niemieckiej, ormiańskiej, rosyjskiej, słowackiej, ukraińskiej, żydowskiej.

Zgodnie z art. 10 ustawy Prawo oświatowe oraz rozporządzeń Ministra Edukacji Narodowej w sprawie warunków organizowania kształcenia, wychowania i opieki dla dzieci i młodzieży niepełnosprawnych, niedostosowanych społecznie i zagrożonych niedostosowaniem społecznym: z dnia 9 sierpnia 2017 r. (par. 5 pkt 2) oraz z dnia 24 lipca 2015 r. (par. 5 pkt 2).

Rozporządzenia Ministra Edukacji Narodowej: z dnia 9 sierpnia 2017 r. w sprawie w sprawie zasad organizacji i udzielania pomocy psychologiczno-pedagogicznej w publicznych przedszkolach, szkołach i placówkach oraz z dnia 30 kwietnia 2013 r. w sprawie zasad udzielania i organizacji pomocy psychologiczno-pedagogicznej w publicznych szkołach i placówkach. 


\section{Instrumenty wsparcia skierowane do dziecka/ucznia}

Przepisy określają wiele instrumentów skierowanych bezpośrednio do dziecka/ucznia ${ }^{46}$. Wśród nich można wyróżnić:

1. Wczesne wspomaganie rozwoju dziecka ${ }^{47}$;

2. Dostosowanie czasu realizacji wychowania przedszkolnego, rozpoczęcia realizacji obowiązku szkolnego oraz okresu kształcenia na poszczególnych etapach edukacyjnych48;

3. Dostosowanie treści programowych ${ }^{49}$, programów nauczania 50 oraz wymagań edukacyjnych do indywidualnych potrzeb rozwojowych i edukacyjnych oraz możliwości psychofizycznych uczniów ${ }^{51}$;

Zdecydowanie więcej jest instrumentów wsparcia skierowanych do dziecka/ucznia niż do innych podmiotów i poziomów oddziaływań. W celu podnoszenia jakości kształcenia i zwiększania uczestnictwa wszystkich uczniów w edukacji włączającej należałoby rozważyć poszerzenie możliwości wsparcia całej klasy z uczniami o różnorodnych potrzebach edukacyjnych oraz nauczyciela, który prowadzi w niej zajęcia.

47 Na podstawie art. 127 ust. 5-9 ustawy Prawo oświatowe oraz Rozporządzenia Ministra Edukacji Narodowej z dnia 24 sierpnia 2017 r. w sprawie organizowania wczesnego wspomagania rozwoju dzieci (Dz.U. poz. 1635).

Art. 31 ust. 2 i 3 oraz art. 36 ust. 1-8 ustawy Prawo oświatowe oraz par. 5-6 Rozporządzenia Ministra Edukacji Narodowej z dnia 28 marca 2017 r. w sprawie ramowych planów nauczania dla publicznych szkół (Dz.U. poz. 703).

Obejmuje wybór podstawy programowej kształcenia ogólnego.

Art. 22a ust. 5 ustawy o systemie oświaty, par. 1 Rozporządzenia Ministra Edukacji Narodowej z dnia 9 sierpnia 2017 r. w sprawie warunków i trybu udzielania zezwoleń na indywidualny program lub tok nauki oraz organizacji indywidualnego programu lub toku nauki (Dz.U. poz. 1569).

Art. 1 pkt 5 ustawy Prawo oświatowe, art. 44c ust. 2 ustawy o systemie oświaty; Rozporządzenie Ministra Edukacji Narodowej z dnia 14 lutego 2017 r. w sprawie podstawy programowej wychowania przedszkolnego oraz podstawy programowej kształcenia ogólnego dla szkoły podstawowej, w tym dla uczniów z niepełnosprawnością intelektualną w stopniu umiarkowanym lub znacznym, kształcenia ogólnego dla branżowej szkoły I stopnia, kształcenia ogólnego dla szkoły specjalnej przysposabiającej do pracy oraz kształcenia ogólnego dla szkoły policealnej (Dz.U. poz. 356 oraz z 2018 r. poz. 1679); par. 2 Rozporządzenia Ministra Edukacji Narodowej z dnia 3 sierpnia 2017 r. w sprawie oceniania, klasyfikowania i promowania uczniów i słuchaczy w szkołach publicznych (Dz.U. poz. 1534); par. 6 ust. 1 pkt 1 rozporządzenia Ministra Edukacji Narodowej z dnia 9 sierpnia 2017 r. w sprawie warunków organizowania kształcenia, wychowania i opieki dla dzieci i młodzieży niepełnosprawnych, niedostosowanych społecznie i zagrożonych niedostosowaniem społecznym; par. 6 ust. 1 pkt 1 rozporządzenia Ministra Edukacji Narodowej z dnia 24 lipca 2015 r. w sprawie warunków organizowania kształcenia, wychowania i opieki dla dzieci i młodzieży niepełnosprawnych, niedostosowanych społecznie i zagrożonych niedostosowaniem społecznym; par. 5 ust. 2 i par. 10 rozporządzenia w sprawie warunków i trybu udzielania zezwoleń na indywidualny program lub tok nauki oraz organizacji indywidualnego programu lub toku nauki. 
4. Dostosowanie warunków i organizacji kształcenia-np. zajęcia edukacyjne $\mathrm{w}$ formie indywidualnej ${ }^{52}$ lub prowadzone $\mathrm{w}$ grupie mniejszej niż oddział klasowy ${ }^{53}$, indywidualny tok nauki ${ }^{54}$, kształcenie specjalne ${ }^{55}$, wsparcie ze strony dodatkowej kadry56, zajęcia umożliwiające uzupełnienie programu nauczania i ustalenie oceny klasyfikacyjnej z lekcji prowadzonych w ramach praktycznej nauki zawodu 57 ;

\section{Brak obowiązku przystępowania do egzaminu ósmoklasisty 58 ; \\ 6. Zwolnienie z egzaminu ósmoklasisty lub z jego części 59 ; \\ 7. Zwolnienie z części egzaminu maturalnego ${ }^{60}$;}

Zajęcia edukacyjne $w$ formie indywidualnej mogą być organizowane na terenie jednostki systemu oświaty, do której uczeń uczęszcza na podstawie przepisów regulujących organizację pomocy psychologiczno-pedagogicznej w przedszkolach, szkołach i placówkach lub organizację kształcenia specjalnego. Indywidualne zajęcia edukacyjne w miejscu zamieszkania dziecka/ ucznia są organizowane na podstawie przepisów rozporządzeń Ministra Edukacji Narodowej: z dnia 9 sierpnia 2017 r. w sprawie indywidualnego obowiązkowego rocznego przygotowania przedszkolnego dzieci i indywidualnego nauczania dzieci i młodzieży (Dz.U. poz. 1616) oraz z dnia 28 sierpnia 2014 r. w sprawie indywidualnego nauczania dzieci i młodzieży (Dz.U. poz. 1157 oraz z 2017 r. poz. 1656).

Na podstawie rozporządzeń Ministra Edukacji Narodowej w sprawie warunków organizowania kształcenia, wychowania i opieki dla dzieci i młodzieży niepełnosprawnych, niedostosowanych społecznie i zagrożonych niedostosowaniem społecznym: z dnia 9 sierpnia 2017 r. (par. 6 ust. 1 pkt 8) oraz $z$ dnia 24 lipca 2015 r. (par. 6 ust. 1 pkt 8).

Art. 111 ustawy Prawo oświatowe oraz rozporządzenie w sprawie warunków i trybu udzielania zezwoleń na indywidualny program lub tok nauki oraz organizacji indywidualnego programu lub toku nauki.

Art. 127 ust. 1 ustawy Prawo oświatowe oraz rozporządzenia Ministra Edukacji Narodowej w sprawie warunków organizowania kształcenia, wychowania i opieki dla dzieci i młodzieży niepełnosprawnych, niedostosowanych społecznie i zagrożonych niedostosowaniem społecznym z dnia 9 sierpnia 2017 r. oraz 24 lipca 2015 r.

O której mowa w przepisach w sprawie warunków organizowania kształcenia, wychowania i opieki dla dzieci i młodzieży niepełnosprawnych, niedostosowanych społecznie i zagrożonych niedostosowaniem społecznym.

Art. 44 I ust. 5 oraz art. $44 z x$ ustawy o systemie oświaty.

Zgodnie art. 44zw ust. 1 ustawy o systemie oświaty uczeń posiadający orzeczenie o potrzebie kształcenia specjalnego wydane ze względu na niepełnosprawność intelektualną w stopniu umiarkowanym lub znacznym lub niepełnosprawności sprzężone, gdy jedną z niepełnosprawności jest niepełnosprawność intelektualna w stopniu umiarkowanym lub znacznym, nie przystępuje do egzaminu ósmoklasisty. Do żadnego z egzaminów zewnętrznych nie przystępują dzieci i młodzieży z niepełnosprawnością intelektualną w stopniu głębokim. 


\section{Zwolnienie z części egzaminu potwierdzającego kwalifikacje} w zawodzie ${ }^{61}$;

9. Możliwość przystąpienia do egzaminu w danym zawodzie lub zawodzie o charakterze pomocniczym przewidzianym dla tego zawodu 62 ;

10. Przystąpienie do egzaminu ósmoklasisty, maturalnego lub potwierdzającego kwalifikacje w zawodzie w terminie dodatkowym ${ }^{63}$;

11. Dostosowanie warunków ${ }^{4}$ i form ${ }^{65}$ przeprowadzania egzaminu ósmoklasisty, maturalnego oraz potwierdzającego kwalifikacje w zawodzie 6 ;

12. Działania o charakterze edukacyjnym, doradczym, wspierającym rozwój lub terapeutycznym - np. zintegrowane działania nauczycieli i specjalistów, zajęcia rozwijające zainteresowania,

Tamże, art. 44zzze ust. 1.

Taką możliwość stworzono od 1 września 2019 r. dla uczniów posiadających orzeczenie o potrzebie kształcenia specjalnego wydane z uwagi na niepełnosprawność, którzy kształcą się w zawodzie, dla którego przewidziano zawód o charakterze pomocniczym. Mogą oni dokonać wyboru i przystąpić do egzaminu zawodowego na podstawie wymagań określonych w podstawie programowej kształcenia w zawodzie szkolnictwa branżowego dla zawodu, w którym się kształcą albo w zawodzie o charakterze pomocniczym.

Tamże: art. 44zz ust. 1, art. 44zzj ust. 1, art. 44zzzga ust. 1.

Na przykład przedłużenie czasu, zapewnienie odpowiednio dostosowanego miejsca pracy, sprzętu specjalistycznego i środków dydaktycznych podczas egzaminu, ustalenie zasad oceniania rozwiązań zadań wykorzystywanych do przeprowadzania egzaminu, uwzględniających potrzeby edukacyjne oraz możliwości psychofizyczne ucznia/absolwenta, zapewnienie obecności i pomocy w czasie egzaminu nauczyciela wspomagającego lub specjalisty odpowiednio z zakresu danego rodzaju niepełnosprawności, niedostosowania społecznego lub zagrożenia niedostosowaniem społecznym, jeżeli jest to niezbędne do uzyskania właściwego kontaktu z uczniem lub pomocy w obsłudze sprzętu specjalistycznego i środków dydaktycznych.

Obejmuje przygotowanie odrębnych arkuszy egzaminacyjnych dostosowanych do potrzeb edukacyjnych zdających, którzy posiadają orzeczenie o potrzebie kształcenia specjalnego wydane z uwagi na niepełnosprawność.

Na podstawie odpowiednio art. 44zzr, art. 44zzzf oraz art. 44zzzh ustawy o systemie oświaty. Szczegółowe sposoby dostosowania w danym roku szkolnym warunków i form przeprowadzania egzaminów zewnętrznych określane są w komunikacie dyrektora Centralnej Komisji Egzaminacyjnej (CKE) wydawanym na podstawie art. 9a ust. 2 pkt 10 lit. a ustawy o systemie oświaty. W szczególnych przypadkach losowych lub zdrowotnych dyrektor szkoły, na wniosek rady pedagogicznej, może wystąpić do dyrektora okręgowej komisji egzaminacyjnej z wnioskiem o wyrażenie zgody na przystąpienie ucznia, słuchacza albo absolwenta do egzaminu ósmoklasisty i egzaminu maturalnego w warunkach dostosowanych do jego potrzeb edukacyjnych oraz możliwości psychofizycznych, nieujętych w komunikacie dyrektora CKE. 
zajęcia z zakresu pomocy psychologiczno-pedagogicznej, zajęcia doradztwa zawodowego, rewalidacyjne, socjoterapeutyczne i resocjalizacyjne.

Do wsparcia nieformalnego ucznia zalicza się np. wolontariat szkolny (Kata 2017), tutoring szkolny ${ }^{67}$ i mediacje rówieśnicze ${ }^{68}$, ale również stwarzanie sytuacji, w których uczeń może rozwijać kompetencje społeczno-emocjonalne, poznać swoje mocne strony i zademonstrować je na forum grupy (np. wycieczki szkolne, przeglądy twórczości dzieci, gry i zawody sportowe).

\section{Wczesna pomoc i wczesne wspomaganie rozwoju dzieci}

Wczesne wspomaganie rozwoju dzieci (WWR) w systemie oświaty organizuje się od chwili wykrycia niepełnosprawności do podjęcia nauki w szkole na podstawie opinii o potrzebie objęcia nim dziecka ${ }^{69}$. Wniosek o wydanie opinii składają rodzice dziecka.

Uzupełnieniem oferty wsparcia skierowanej do małych dzieci i ich rodzin jest rządowy program kompleksowego wsparcia rodzin "Za życiem"70, realizowany w latach 2017-2021. W jego ramach przewidziano powołanie na terenie powiatów ośrodków koordynacyjno-rehabilitacyjno-opiekuńczych (OKRO) ${ }^{71}$. To właśnie w tych instytucjach wczesną, specjalistyczną opieką mogą być obejmowane również dzieci zagrożone niepełnosprawnością oraz ich rodziny na podstawie zaświadczenia lekarskiego. OKRO zapewniają możliwość dodatkowych oddziaływań terapeutycznych i rehabilitacyjnych, zgodnie z potrzebami dzieci, a także opiekę pielęgniarską i konsultacje lekarzy specjalistów. Udzielenie pomocy przez OKRO następuje z inicjatywy rodzica.

Opinie te wydawane są przez zespoły orzekające działające w publicznych poradniach psychologiczno-pedagogicznych na podstawie art. 127 ust. 10 ustawy z dnia 14 grudnia 2016 r. Prawo oświatowe oraz Rozporządzenia Ministra Edukacji Narodowej z dnia 7 września 2017 r. w sprawie orzeczeń i opinii wydawanych przez zespoły orzekające działające w publicznych poradniach psychologiczno-pedagogicznych (Dz.U. poz. 1743). wsparcia dla rodzin "Za życiem" (M.P. poz. 1250).

71 Rozporządzenie Ministra Edukacji Narodowej z dnia 5 września 2017 r. w sprawie szczegółowych zadań wiodących ośrodków koordynacyjno-rehabilitacyjno-opiekuńczych (Dz.U. poz. 1712). 


\section{Dostosowanie czasu rozpoczęcia i zakończenia ksztalcenia na danym etapie edukacyjnym}

Dziecko może rozpocząć realizację obowiązku szkolnego wcześniej o jeden rok szkolny niż jego rówieśnicy, tj. w wieku sześciu lat. Jest to możliwe w sytuacji, gdy korzystało ono $z$ wychowania przedszkolnego w roku szkolnym poprzedzającym ten, w którym ma rozpocząć naukę w szkole podstawowej, bądź gdy posiada opinię poradni psychologiczno-pedagogicznej ${ }^{72}$. Decyzję w tej sprawie na wniosek rodzica podejmuje dyrektor szkoły ${ }^{73}$.

Możliwe jest również odroczenie realizacji obowiązku szkolnego o jeden rok, a w przypadku dzieci z niepełnosprawnością objętych kształceniem specjalnym, nawet o dwa lata ${ }^{74}$. Decyzję podejmuje dyrektor szkoły podstawowej na podstawie składanego przez rodziców wniosku, do którego dołączana jest opinia poradni psychologiczno-pedagogicznej, stwierdzająca potrzebę odroczenia spełniania przez dziecko obowiązku szkolnego $w$ danym roku. Decyzja dotyczy zawsze jednego roku szkolnego, zatem jeśli rodzice dziecka z niepełnosprawnością objętego kształceniem specjalnym ubiegają się o odroczenie w kolejnym, muszą ponownie złożyć wniosek wraz z nową opinią poradni $w$ tej sprawie. Zastosowanie tego mechanizmu wskazuje na konieczność monitorowania postępów dziecka oraz podejmowanie decyzji na podstawie aktualnej oceny jego potrzeb.

Dzieci, u których stwierdzono niepełnosprawność intelektualną w stopniu głębokim, już w wieku trzech lat mogą rozpocząć realizację zajęć rewalidacyjno-wychowawczych ${ }^{75}$. Udział w nich wypełnia obowiązek rocznego przygotowania przedszkolnego, obowiązek szkolny i nauki ${ }^{76}$, jest więc obligatoryjny od 6 do 18 roku życia. Zajęcia te mogą być organizowane do końca roku szkolnego, w którym uczestnik zajęć pracowników posiadających kwalifikacje określone dla pracowników publicznych poradni psychologiczno-pedagogicznych.

Art. 36 ust. 1 i 2 ustawy Prawo oświatowe.

Na podstawie orzeczenia o potrzebie zajęć rewalidacyjno-wychowawczych wydanego przez zespół orzekający działający w publicznej poradni psychologiczno-pedagogicznej, w tym specjalistycznej. 
kończy 25 lat. Decyzję o czasie rozpoczęcia i zakończenia uczestnictwa dziecka podejmują rodzice.

Przedłużono możliwość nauki na poszczególnych etapach edukacyjnych uczniom objętym kształceniem specjalnym. W szkole podstawowej może być ono prowadzone do końca roku szkolnego w tym roku kalendarzowym, w którym uczeń kończy 20 lat, a w szkole ponadpodstawowej -24 lata.

Przewidziano również możliwość przedłużenia okresu kształcenia na poszczególnych etapach edukacyjnych: w szkole podstawowej łącznie o trzy lata (o jeden rok na I i o dwa lata na II etapie edukacyjnym), a w szkole ponadpodstawowej - o jeden rok ${ }^{77}$. Możliwość ta dotyczy uczniów z niepełnosprawnością objętych kształceniem specjalnym oraz uczniów szkół w zakładach poprawczych i w schroniskach dla nieletnich. Przedłużenie okresu nauki jest instrumentem skierowanym do konkretnego ucznia, a nie do całej klasy - każdorazowo decyzja w tej sprawie powinna być podejmowania z uwzględnieniem jego indywidualnej sytuacji, gdy ma on znaczne trudności w opanowaniu wymagań określonych w podstawie programowej kształcenia ogólnego lub w osiągnięciu efektów kształcenia określonych w podstawie programowej kształcenia w danym zawodzie. Decyzję o przedłużeniu okresu nauki uczniowi z orzeczeniem o potrzebie kształcenia specjalnego wydanym ze względu na niepełnosprawność podejmuje rada pedagogiczna po uzyskaniu opinii zespołu nauczycieli i specjalistów prowadzących z nim zajęcia oraz zgody rodziców albo pełnoletniego ucznia ${ }^{78}$.

Istnieje również możliwość skrócenia okresu kształcenia. Mogą z niej skorzystać uczniowie szczególnie uzdolnieni, którzy realizują indywidualny tok nauki ${ }^{79}$. Są oni klasyfikowani na podstawie egzaminów. po uzyskaniu opinii rady pedagogicznej. na indywidualny program lub tok nauki oraz organizacji indywidualnego programu lub toku nauki (Dz.U. poz. 1569). 
Możliwość skrócenia okresu kształcenia, ale tylko w branżowej szkole I stopnia z trzech do dwóch lat ${ }^{80}$, przewidziano w przypadku uczniów szkół działających w:

$\rightarrow$ młodzieżowych ośrodkach wychowawczych lub młodzieżowych ośrodkach socjoterapii, którzy posiadają orzeczenie o potrzebie kształcenia specjalnego wydane ze względu na niedostosowanie społeczne lub zagrożenie niedostosowaniem społecznym,

$\rightarrow$ zakładach poprawczych lub schroniskach dla nieletnich ${ }^{81}$.

Decyzję o skróceniu podejmuje rada pedagogiczna po konsultacjach z rodzicami ucznia oraz po uzyskaniu opinii zespołu nauczycieli i specjalistów prowadzących z nim zajęcia.

\section{Dostosowanie treści nauczania oraz wymagań edukacyjnych}

\section{Treści nauczania}

System oświaty zapewnia dostosowanie treści nauczania ${ }^{22}$. Dzieci objęte wychowaniem przedszkolnym, niezależnie od tego, czy rozpoznano u nich specjalne potrzeby edukacyjne (z wyjątkiem dzieci z niepełnosprawnością intelektualną w stopniu głębokim), czy nie, realizują tę samą podstawę programową wychowania przedszkolnego ${ }^{83}$. Na poziomie szkoły podstawowej i gimnazjum (do czasu ich wygaszenia) określono odrębną podstawę programową dla uczniów z niepełnosprawnością edukacyjnych, przewidzianego dla trzyletniego okresu nauczania, z tym, że wymiar godzin zajęć wychowania fizycznego określa art. 28 ust. 2 ustawy Prawo oświatowe.

81 Na podstawie par. 6 rozporządzenia Ministra Edukacji Narodowej w sprawie ramowych planów nauczania dla publicznych szkół.

Załącznik nr 1 do rozporządzenia Ministra Edukacji Narodowej z dnia 14 lutego 2017 r. w sprawie podstawy programowej wychowania przedszkolnego oraz podstawy programowej kształcenia ogólnego dla szkoły podstawowej, w tym dla uczniów z niepełnosprawnością intelektualną w stopniu umiarkowanym lub znacznym, kształcenia ogólnego dla branżowej szkoły I stopnia, kształcenia ogólnego dla szkoły specjalnej przysposabiającej do pracy oraz kształcenia ogólnego dla szkoły policealnej (Dz.U. poz. 356). 
intelektualną w stopniu umiarkowanym lub znacznym ${ }^{84}$. Na etapie kształcenia ponadpodstawowego lub ponadgimnazjalnego uczniowie ci realizują podstawę programową szkoły specjalnej przysposabiającej do pracy ${ }^{85}$. W tym typie szkoły uczyć się mogą również uczniowie z niepełnosprawnościami sprzężonymi. Pozostali realizują tę samą podstawę programową kształcenia ogólnego określoną dla szkół danego typu ${ }^{86}$ oraz odpowiednio: podstawę programową kształcenia w zawodach ${ }^{87}$ lub podstawy kształcenia w zawodach szkolnictwa branżowego88.

Wybór realizowanej podstawy kształcenia ogólnego wynika zatem z określonego w orzeczeniu poziomu rozwoju intelektualnego ucznia. Wniosek o wydanie orzeczenia składają rodzice ucznia lub pełnoletni uczeń. Mogą oni w każdej chwili wystąpić o zmianę lub uchylenie orzeczenia.

Określoną wzałączniku nr 3 do rozporządzenia Ministra Edukacji Narodowejz dnia 14 lutego 2017 r. w sprawie podstawy programowej wychowania przedszkolnego oraz podstawy programowej kształcenia ogólnego dla szkoły podstawowej, w tym dla uczniów z niepełnosprawnością intelektualną w stopniu umiarkowanym lub znacznym, kształcenia ogólnego dla branżowej szkoły I stopnia, kształcenia ogólnego dla szkoły specjalnej przysposabiającej do pracy oraz kształcenia ogólnego dla szkoły policealnej oraz w załączniku nr 3 do Rozporządzenia Ministra Edukacji Narodowej z dnia 27 sierpnia 2012 r. w sprawie podstawy programowej wychowania przedszkolnego oraz kształcenia ogólnego w poszczególnych typach szkół (Dz.U. poz. 977 z późn. zm.).

85 Określoną w załączniku nr 5 do ww. rozporządzenia z dnia 14 lutego 2017 r. oraz w załączniku nr 7 do ww. rozporządzenia z dnia 27 sierpnia 2012 r.

Załączniki nr 2, 4 i 6 do Rozporządzenia Ministra Edukacji Narodowej z dnia 14 lutego 2017 r. w sprawie podstawy programowej wychowania przedszkolnego oraz podstawy programowej kształcenia ogólnego dla szkoły podstawowej, w tym dla uczniów z niepełnosprawnością intelektualną w stopniu umiarkowanym lub znacznym, kształcenia ogólnego dla branżowej szkoły I stopnia, kształcenia ogólnego dla szkoły specjalnej przysposabiającej do pracy oraz kształcenia ogólnego dla szkoły policealnej oraz załączniki nr 2, 4, 5 i 6 do Rozporządzenia Ministra Edukacji Narodowej z dnia 27 sierpnia 2012 r. w sprawie podstawy programowej wychowania przedszkolnego oraz kształcenia ogólnego w poszczególnych typach szkół (Dz.U. poz. 977 z późn. zm.) - dotyczy tzw. szkół starego typu (sześcioletnia szkoła podstawowa, gimnazjum, zasadnicza szkoła zawodowa, trzyletnie liceum ogólnokształcące, czteroletnie technikum, szkoła policealna).

Rozporządzenie Ministra Edukacji Narodowej z dnia 31 marca 2017 r. w sprawie podstawy programowej kształcenia w zawodach (Dz.U. poz. 860).

Rozporządzenie Ministra Edukacji Narodowej z dnia 16 maja 2019 r. w sprawie podstaw programowych kształcenia w zawodach szkolnictwa branżowego oraz dodatkowych umiejętności zawodowych w zakresie wybranych zawodów szkolnictwa branżowego (Dz.U. poz. 991). Dotyczy uczniów, którzy rozpoczynają naukę w szkole prowadzącej kształcenie zawodowe od 1 września 2019 r. 
Programy wychowania przedszkolnego, programy nauczania zajęć edukacyjnych z zakresu kształcenia ogólnego na dany etap edukacyjny oraz programy nauczania zawodu są dopuszczane do użytku w danym przedszkolu, oddziale przedszkolnym w szkole podstawowej, innej formie wychowania przedszkolnego lub w szkole przez dyrektora po zasięgnięciu opinii rady pedagogicznej. Programy te powinny być dostosowane do potrzeb i możliwości uczniów, dla których są przeznaczone.

Dzieci i młodzież z niepełnosprawnością intelektualną w stopniu głębokim realizują indywidualne programy rewalidacyjno-wychowawcze. Ich zakres powinien być dostosowany do poziomu funkcjonowania uczestnika zajęćs9. Nie realizuje on zatem podstawy programowej, nie podlega przepisom w sprawie oceniania, klasyfikowania i promowania, nie otrzymuje świadectwa lub innego równoważnego dokumentu. Nie obowiązuje także podział na poszczególne etapy edukacji, co jest istotne w sytuacji zmiany kwalifikacji orzeczenia o potrzebie zajęć rewalidacyjno-wychowawczych na orzeczenie o potrzebie kształcenia specjalnego. Postulat zmiany tego stanu rzeczy jest zgłaszany przez środowiska pedagogiczne oraz Rzecznika Praw Obywatelskich ${ }^{90}$. Zasadność zastosowania takich rozwiązań w odniesieniu do osób o bardzo niskim poziomie funkcjonowania jest dla części pedagogów kontrowersyjna, biorąc pod uwagę konieczność stawiania wymagań edukacyjnych w sytuacji, gdy często zakres oddziaływań może dotyczyć wąskiego obszaru funkcjonowania. W świetle postanowień ratyfikowanej przez Polskę konwencji ONZ o prawach osób niepełnosprawnych ${ }^{91}$, kwestia ta wymaga pogłębionej analizy i społecznej dyskusji w związku z koniecznością zapewnienia wszystkim osobom z niepełnosprawnością, w tym także intelektualną w stopniu głębokim, równego dostępu do edukacji. Poparcie dla zasadności opracowania jednej podstawy programowej kształcenia ogólnego dla wszystkich uczniów, uwzględniającej szerokie spektrum ich funkcjonowania, zawarto $\mathrm{w}$ rekomendacjach organizowania zajęć rewalidacyjno-wychowawczych dla dzieci i młodzieży z upośledzeniem umysłowym w stopniu głębokim (Dz.U. poz. 529). osób z głęboką niepełnosprawnością intelektualną, bit.ly/2K3sqc4 [dostęp: 6.06.2019]. 
Europejskiej Agencji do spraw Specjalnych Potrzeb i Edukacji Włączającej (2019, s. 9).

Uczeń, który przejawia szczególne uzdolnienia, może realizować indywidualny program nauki z jednego, kilku lub wszystkich obowiązujących zajęć edukacyjnych przewidzianych $w$ tygodniowym planie dla danej klasy ${ }^{92}$.

Dla osób podlegających obowiązkowi szkolnemu lub obowiązkowi nauki, które nie opanowały języka polskiego albo znają go na poziomie niewystarczającym do korzystania z nauki ${ }^{93}$, przewidziano możliwość dodatkowej, bezpłatnej nauki języka polskiego ${ }^{94}$.

W przypadku dzieci i młodzieży z mniejszości narodowych i etnicznych możliwa jest organizacja nauki ich języka ojczystego oraz zajęć z zakresu ich historii i kultury ${ }^{9}$. Decyzja dotycząca udziału dziecka w tych zajęciach należy do rodziców.

Istnieje również możliwość zwolnienia ucznia z realizacji określonych zajęć edukacyjnych ${ }^{\circ}$. Może ono dotyczyć m.in. nauki drugiego języka nowożytnego w przypadku uczniów z wadą słuchu, z głęboką dysleksją rozwojową, z afazją, z niepełnosprawnościami sprzężonymi lub $z$ autyzmem, w tym z zespołem Aspergera. Zwolnienie następuje wyłącznie na wniosek rodzica i wówczas, gdy takie wskazanie zostato zawarte opinii wydanej uczniowi przez poradnię psychologiczno-pedagogiczną albo w orzeczeniu o potrzebie kształcenia specjalnego lub indywidualnego nauczania. Możliwe jest również zwolnienie $z$ informatyki lub zajęć wychowania fizycznego ${ }^{97}$, albo z wykonywania

Zgodnie z art. 115 ustawy Prawo oświatowe oraz rozporządzeniem w sprawie warunków i trybu udzielania zezwoleń na indywidualny program lub tok nauki oraz organizacji indywidualnego programu lub toku nauki.

Zarówno osób niebędących obywatelami polskimi, jak i obywateli polskich.

Zgodnie z art. 165 ust. 7 i 9 ustawy Prawo oświatowe. Dodatkową naukę języka polskiego dla tych osób organizuje organ prowadzący szkołę.

Rozporządzenie Ministra Edukacji Narodowej z dnia 18 sierpnia 2017 r. w sprawie warunków i sposobu wykonywania przez przedszkola, szkoły i placówki publiczne zadań umożliwiających podtrzymywanie poczucia tożsamości narodowej, etnicznej i językowej uczniów należących do mniejszości narodowych i etnicznych oraz społeczności posługującej się językiem regionalnym (Dz.U. poz. 1627).

Par. 4-6 rozporządzenia Ministra Edukacji Narodowej w sprawie oceniania, klasyfikowania i promowania uczniów i słuchaczy w szkołach publicznych. 
określonych ćwiczeń fizycznych ${ }^{98}$. Stosowne dokumenty przedkładane są przez rodziców.

\section{Dostosowanie warunków i organizacji procesu uczenia się i nauczania}

Dla dzieci objętych wychowaniem przedszkolnym oraz uczniów szkół podstawowych i ponadpodstawowych, którzy w związku z występowaniem niepełnosprawności 99 , niedostosowania społecznego lub zagrożenia niedostosowaniem społecznym ${ }^{100}$ wymagają specjalnej organizacji nauki i metod pracy, organizuje się, zgodnie z decyzją rodziców ${ }^{101}$, kształcenie specjalne ${ }^{102}$. Istnieje możliwość wyboru różnych form jego organizacji: w przedszkolach, szkołach i oddziałach ogólnodostępnych, integracyjnych i specjalnych oraz placówkach specjalnych. Zalecaną formę kształcenia specjalnego wskazuje w orzeczeniu zespół orzekający, jednak decyzja ta należy ostatecznie do rodziców lub pełnoletniego ucznia ${ }^{103}$.

Uczniowie objęci kształceniem specjalnym mogą realizować zajęcia w sposób dostosowany do ich potrzeb na podstawie indywidualnego programu edukacyjno-terapeutycznego: $z$ oddziałem klasowym, w grupie do pięciu osób lub indywidualnie na terenie szkoły. Analogiczne możliwości dotyczą dzieci objętych wychowaniem przedszkolnym.

W przepisach prawa oświatowego katalog niepełnosprawności, w związku z którymi organizuje się kształcenie specjalne, jest ściśle określony i dotyczy dzieci i uczniów: niewidomych, słabowidzących, niesłyszących, słabosłyszących, z niepełnosprawnością intelektualną w stopniu lekkim, umiarkowanym i znacznym, z autyzmem, w tym zespołem Aspergera, z niepełnosprawnością ruchową, w tym z afazją, oraz z niepełnosprawnościami sprzężonymi.

W przypadku dzieci objętych wychowaniem przedszkolnym kształcenie specjalne organizuje się wyłącznie z uwagi na niepełnosprawność. W tym wieku nie stwierdza się niedostosowania społecznego lub zagrożenia nim.

101 To rodzice występują o wydanie orzeczenia o potrzebie kształcenia specjalnego. W każdej chwili mogą zmienić zdanie w tej sprawie i złożyć wniosek o zmianę lub uchylenie takiego orzeczenia.

103 Nie dotyczy to nieletnich, wobec których sąd rodzinny orzekł umieszczenie w młodzieżowym ośrodku wychowawczym. 
We wszystkich typach szkół istnieje możliwość organizacji klas terapeutycznych ${ }^{104}$. Ta forma przewidziana jest dla uczniów, którzy wymagają dostosowania organizacji i procesu nauczania oraz długotrwałej pomocy specjalistycznej z uwagi na trudności w funkcjonowaniu wynikające z zaburzeń rozwojowych lub ze stanu zdrowia. Podstawą przyjęcia ucznia do takiej klasy jest opinia poradni psychologiczno-pedagogicznej, z której wynika potrzeba objęcia ucznia pomocą w tej formie.

W szkołach ${ }^{105}$ mogą być również tworzone oddziały przygotowawcze ${ }^{106}$ dla osób ${ }^{107}$ podlegających obowiązkowi szkolnemu lub obowiązkowi nauki, które nie znają języka polskiego albo opanowały go na poziomie niewystarczającym i wymagają dostosowania procesu kształcenia do ich potrzeb i możliwości edukacyjnych.

Stworzono również możliwość kształcenia bez konieczności udziału w obowiązkowych zajęciach edukacyjnych. Korzystają z niej uczniowie realizujący indywidualny tok nauki ${ }^{108}$. Jego organizacja odbywa się na wniosek rodziców, ucznia ${ }^{109}$, wychowawcy klasy lub nauczyciela prowadzącego dane zajęcia ( $w$ takim przypadku konieczna jest zgoda rodziców albo pełnoletniego ucznia).

Dzieci objęte rocznym obowiązkowym wychowaniem przedszkolnym oraz uczniowie szkół wszystkich typów mają możliwość realizowania zindywidualizowanych ścieżek wychowania przedszkolnego

Par. 13 rozporządzenia Ministra Edukacji Narodowej z dnia 9 sierpnia 2017 r. w sprawie zasad organizacji i udzielania pomocy psychologiczno-pedagogicznej w publicznych przedszkolach, szkołach i placówkach oraz par. 8 rozporządzenia Ministra Edukacji Narodowej z dnia 30 kwietnia 2013 r. w sprawie zasad udzielania i organizacji pomocy psychologiczno-pedagogicznej w publicznych szkołach i placówkach. Klas takich nie tworzy się w szkołach specjalnych.

105 Z wyjątkiem szkół artystycznych, specjalnych, sportowych, mistrzostwa sportowego i szkół dla dorosłych.

Art. 165 ust. 11-14 ustawy - Prawo oświatowe oraz Rozporządzenia Ministra Edukacji Narodowej z dnia 23 sierpnia 2017 r. w sprawie kształcenia osób niebędących obywatelami polskimi oraz osób będących obywatelami polskimi, które pobierały naukę w szkołach funkcjonujących w systemach oświaty innych państw (Dz.U. poz.1655).

107 Dotyczy to osób zarówno będących, jak i niebędących obywatelami polskimi.

108 Par. 2 rozporządzenia Ministra Edukacji Narodowej w sprawie warunków i trybu udzielania zezwoleń na indywidualny program lub tok nauki oraz organizacji indywidualnego programu lub toku nauki. 
lub kształcenia w szkole ${ }^{110}$. Ta forma kierowana jest do uczniów, którzy mogą uczęszczać do przedszkola lub szkoły, ale ze względu na trudności w funkcjonowaniu nie mogą uczestniczyć we wszystkich zajęciach wraz z rówieśnikami. Organizacja zindywidualizowanych ścieżek odbywa się na wniosek rodzica albo pełnoletniego ucznia i wymaga posiadania opinii publicznej poradni psychologiczno-pedagogicznej. Uczeń, który korzysta z tej ścieżki kształcenia, część zajęć realizuje z klasą, a część indywidualnie z nauczycielem ${ }^{111}$.

Uczniowie, których stan zdrowia znacznie utrudnia lub uniemożliwia uczęszczanie do szkoły, są objęci indywidualnym nauczaniem ${ }^{112}$. Zajęcia organizowane są w miejscu zamieszkania lub pobytu ucznia. Do wniosku o wydanie stosownego orzeczenia oraz zawieszenie lub zaprzestanie organizacji zajęć dołącza się zaświadczenie lekarskie. Dyrektor zobowiązany jest zasięgnąć opinii odpowiednio: rodziców albo pełnoletniego ucznia w zakresie czasu prowadzenia zajęć indywidualnego nauczania, jak i odstąpienia od realizacji niektórych treści nauczania ${ }^{113}$. Na wniosek rodziców tygodniowy wymiar godzin tych zajęć może być niższy niż minimalne wymagania określone w przepisach (np. w sytuacji, gdy stan zdrowia znacznie ogranicza dziecku możliwość udziału w zajęciach). W uzgodnieniu z rodzicami albo z pełnoletnim uczniem podejmowane są także działania umożliwiające mu kontakt z kolegami z klasy. Analogiczne regulacje dotyczą organizacji indywidualnego rocznego przygotowania przedszkolnego.

Rozwiązanie to nie obejmuje dzieci i uczniów objętych kształceniem specjalnym - dostosowanie organizacji w ich przypadku następuje na podstawie ustaleń zawartych $w$ indywidualnych programach edukacyjno-terapeutycznych. Ścieżek takich nie stosuje się zatem w przedszkolach i szkołach specjalnych.

Par. 12 rozporządzenia Ministra Edukacji Narodowej z dnia 9 sierpnia 2017 r. w sprawie zasad organizacji i udzielania pomocy psychologiczno-pedagogicznej w publicznych przedszkolach, szkołach i placówkach oraz par. 13b rozporządzenia Ministra Edukacji Narodowej z dnia 30 kwietnia 2013 r. w sprawie zasad udzielania i organizacji pomocy psychologiczno-pedagogicznej w publicznych szkołach i placówkach.

Art. 127 ustawy Prawo oświatowe oraz rozporządzeń Ministra Edukacji Narodowej: z dnia 9 sierpnia 2017 r. w sprawie indywidualnego obowiązkowego rocznego przygotowania przedszkolnego dzieci i indywidualnego nauczania dzieci i młodzieży oraz z dnia 28 sierpnia 2014 r. w sprawie indywidualnego obowiązkowego rocznego przygotowania przedszkolnego dzieci i indywidualnego nauczania dzieci i młodzieży. 
W szkołach podstawowych mogą być tworzone oddziały przysposabiające do pracy ${ }^{114}$. Przeznaczone są dla uczniów w wieku powyżej 15 lat, którzy otrzymali promocję do klasy VII albo nie uzyskali do klasy VIII i mogą mieć trudności z ukończeniem szkoły w normalnym trybie ${ }^{115}$. Naukę $w$ tych oddziałach realizuje się zgodnie z podstawą programową kształcenia ogólnego dostosowaną do potrzeb i możliwości uczniów. Przyjęcie do takiego oddziału wymaga opinii lekarza oraz poradni psychologiczno-pedagogicznej. Dokumenty te wydawane są wyłącznie na wniosek rodzica lub pełnoletniego ucznia.

\section{Podręczniki i materiały dydaktyczne}

Dostosowanie procesu kształcenia obejmuje również odpowiedni do potrzeb edukacyjnych uczniów dobór podręczników, materiałów edukacyjnych i ćwiczeniowych, a także ich formy (papierowa, elektroniczna). Nauczyciel ma w tym zakresie dużą autonomię. Może zdecydować o realizacji programu nauczania z zastosowaniem podręcznika, materiału edukacyjnego lub materiału ćwiczeniowego albo zrezygnować z ich stosowania ${ }^{116}$. Wybierając materiały dydaktyczne dla uczniów z niepełnosprawnością objętych kształceniem specjalnym, nauczyciele zobowiązani są do uwzględniania ich potrzeb edukacyjnych i możliwości psychofizycznych ${ }^{117}$. Na zakup podręczników, materiałów edukacyjnych i ćwiczeniowych dostosowanych do potrzeb tych uczniów przeznaczane są zwiększone środki w ramach dotacji celowej ${ }^{118}$. Nauczyciele mogą również korzystać z przygotowanych na zlecenie Ministerstwa Edukacji Narodowej podręczników, materiałów edukacyjnych oraz książek pomocniczych, dostosowanych do potrzeb uczniów z niepełnosprawnością ${ }^{119}$.

114 Par. 16 rozporządzenia Ministra Edukacji Narodowej w sprawie szczegółowej organizacji publicznych szkół i publicznych przedszkoli.

115 Przepisy nie precyzują przesłanek, które powinny być uwzględnione w ocenie takiego stanu. Art. 22ab ust. 1 ustawy o systemie oświaty (Dz.U. poz. 1591 z późn. zm.).

117 Tamże, art. 22ab ust. 3.

118 Art. 55 ust. 6 ustawy o finansowaniu zadań oświatowych.

119 Adaptacje podręczników szkolnych i książek pomocniczych, dostosowane do potrzeb uczniów niewidomych, słabowidzących i niesłyszących, bit.ly/2Wrsp38 [dostęp: 6.06.2019]. 


\section{Wsparcie dodatkowej kadry}

Przepisy prawa oświatowego umożliwiają zatrudnianie osób wspierających organizację kształcenia specjalnego: nauczycieli posiadających przygotowanie w zakresie pedagogiki specjalnej, specjalistów oraz pomocy nauczyciela.

W przedszkolach ogólnodostępnych z oddziałami integracyjnymi, przedszkolach integracyjnych, szkołach ogólnodostępnych z oddziałami integracyjnymi i szkołach integracyjnych zatrudnia się dodatkowo nauczycieli posiadających kwalifikacje w zakresie pedagogiki specjalnej, którzy współorganizują proces edukacyjny z uwzględnieniem zaleceń zawartych w orzeczeniu o potrzebie kształcenia specjalnego.

Dodatkową kadrę obowiązkowo zatrudnia się także w szkołach ogólnodostępnych, do których uczęszczają uczniowie posiadający orzeczenie o potrzebie kształcenia specjalnego wydane ze względu na autyzm, w tym zespół Aspergera, albo niepełnosprawności sprzężone. Kadra ta, w zależności od potrzeb, składa się z nauczycieli posiadających kwalifikacje w zakresie pedagogiki specjalnej, specjalistów lub pomocy nauczyciela. Zajęcia edukacyjne oraz zintegrowane działania i określone w programie lekcje, realizowane wspólnie z innymi nauczycielami przez dodatkowo zatrudnione osoby wyznacza dyrektor szkoły, kierując się potrzebami uczniów. W ocenie tych potrzeb oraz efektywności udzielonego wsparcia mają prawo uczestniczyć rodzice i sami uczniowie. Analogiczne przepisy obowiązują również w przedszkolach ogólnodostępnych oraz w innych formach wychowania przedszkolnego.

Rodzice dziecka posiadającego orzeczenie o niepełnosprawności lub stopniu niepełnosprawności ${ }^{120}$ mogą ponadto wystąpić do właściwego ośrodka pomocy społecznej z wnioskiem o zatrudnienie asystenta osoby niepełnosprawnej ${ }^{121}$.

Wszyscy uczniowie podlegający obowiązkowi szkolnemu lub obowiązkowi nauki (także cudzoziemcy), którzy nie znają języka polskiego albo znają go na poziomie niewystarczającym, mogą skorzystać z pomozawodowej i społecznej oraz zatrudnianiu osób niepełnosprawnych (Dz.U. z 2018 r. poz. 511 z późn. zm.) oraz Rozporządzenia Ministra Gospodarki, Pracy i Polityki Społecznej z dnia 15 lipca 2003 r. w sprawie orzekania o niepełnosprawności i stopniu niepełnosprawności (Dz.U. z 2018 r. poz. 2027). 
cy osoby władającej językiem kraju pochodzenia. Zatrudnia ją dyrektor szkoły w charakterze pomocy nauczyciela na okres nie dłuższy niż 12 miesięcy ${ }^{122}$. Takie regulacje nie istnieją w odniesieniu do przedszkoli.

Do wspomagania nauczyciela mogą także być zatrudniani w przedszkolach i szkołach publicznych asystenci edukacji romskiej, którzy udzielają dzieciom i młodzieży pochodzenia romskiego pomocy w kontaktach ze środowiskiem przedszkolnym lub szkolnym, ponadto współpracują z ich rodzicami oraz z przedszkolem lub szkołą123.

\section{Oddziaływania o charakterze edukacyjnym, doradczym, wspierającym rozwój lub terapeutycznym}

W przepisach określono wiele możliwości rozwijania zainteresowań, zdolności, umiejętności i kompetencji uczniów, a także niwelowania występujących deficytów i zaburzeń rozwojowych.

\section{Oferta przedszkoli, szkół i placówek}

Nauczyciele, opiekunowie grup wychowawczych oraz specjaliści zobowiązani są do udzielania pomocy psychologiczno-pedagogicznej podczas bieżącej pracy z uczniami. Jest to bardzo ważny i najbardziej dostępny instrument wsparcia, jednakże aby był skuteczny, trzeba go realizować na podstawie jasno zdefiniowanych celów. Konieczne jest także monitorowanie postępów uczniów. W przepisach wskazano również jeszcze jedno ważne narzędzie - zintegrowane działania nauczycieli i specjalistów. Przykładem mogą być prace ukierunkowane na wzmacnianie poczucia własnej wartości ucznia, nagradzanie pożądanych zachowań czy rozwijanie jego kompetencji komunikacyjnych, które są realizowane przez wszystkich nauczycieli w trakcie lekcji oraz podczas zajęć świetlicowych. W przypadku ucznia z niepełnosprawnością będą to działania o charakterze rewalidacyjnym, ucznia niedosto-

Par. 12 ust. 2 Rozporządzenia Ministra Edukacji Narodowej z dnia 18 sierpnia 2017 r. w sprawie warunków i sposobu wykonywania przez przedszkola, szkoły i placówki publiczne zadań umożliwiających podtrzymywanie poczucia tożsamości narodowej, etnicznej i językowej uczniów należących do mniejszości narodowych i etnicznych oraz społeczności posługującej się językiem regionalnym (Dz.U. poz. 1627). 
sowanego społecznie - resocjalizacyjnym, a zagrożonego niedostosowaniem społecznym - socjoterapeutycznym ${ }^{124}$.

W ramach zajęć świetlicowych mogą być prowadzone różnorodne zajęcia uwzględniające potrzeby edukacyjne oraz rozwojowe uczniów, ukierunkowane na rozwijanie zainteresowań uczniów, wspieranie rozwoju fizycznego czy pomoc w odrabianiu lekcji ${ }^{125}$.

Przedszkola, szkoły i placówki zapewniają również szeroki wachlarz zajęć z zakresu pomocy psychologiczno-pedagogicznej ${ }^{126}$. Dla uczniów napotykających trudności w uczeniu się, szczególnie w spełnianiu wymagań edukacyjnych wynikających z podstawy programowej kształcenia ogólnego dla danego etapu edukacyjnego, organizuje się zajęcia dydaktyczno-wyrównawcze. Dostępne są też zajęcia rozwijające zainteresowania i uzdolnienia, które służą zwłaszcza kształtowaniu aktywności i kreatywności uczniów, realizowane np. w ramach warsztatów, kółek zainteresowań, gier terenowych czy zajęć plenerowych. Przepisy nie precyzują ich zakresu i formy, pozostawiając przestrzeń na dostosowanie ich do potrzeb konkretnych uczniów. Zajęcia rozwijające umiejętności uczenia się powinny być dostępne dla wszystkich dzieci, a nie tylko dla tych, które mają trudności w nauce. Ich celem jest bowiem przekazanie technik skutecznego uczenia się, których znajomość jest niezbędna na każdym etapie kształcenia. W przedszkolach, szkołach i placówkach mogą być również organizowane różnego rodzaju zajęcia specjalistyczne, np. korekcyjno-kompensacyjne, logopedyczne, rozwijające kompetencje emocjonalno-społeczne.

Dla dzieci i uczniów z niepełnosprawnością organizowane są różnego rodzaju zajęcia rewalidacyjne ${ }^{127}$, których rodzaj oraz forma (indywi-

124 Na podstawie rozporządzeń Ministra Edukacji Narodowej w sprawie warunków organizowania kształcenia, wychowania i opieki dla dzieci i młodzieży niepełnosprawnych, niedostosowanych społecznie i zagrożonych niedostosowaniem społecznym: z dnia 9 sierpnia 2017 r. oraz z dnia 24 lipca 2015 r.

Art. 105 ust. 2 ustawy Prawo oświatowe.

Na podstawie przepisów rozporządzeń Ministra Edukacji Narodowej z dnia 9 sierpnia 2017 r. w sprawie zasad organizacji i udzielania pomocy psychologiczno-pedagogicznej w publicznych przedszkolach, szkołach i placówkach oraz z dnia 30 kwietnia 2013 r. w sprawie zasad udzielania i organizacji pomocy psychologiczno-pedagogicznej w publicznych szkołach i placówkach.

Art. 1 i 109 ustawy Prawo oświatowe oraz rozporządzeń Ministra Edukacji Narodowej w sprawie warunków organizowania kształcenia, wychowania i opieki dla dzieci i młodzieży niepełnosprawnych, niedostosowanych społecznie i zagrożonych niedostosowaniem społecznym: z dnia 9 sierpnia 2017 r. oraz z dnia 24 lipca 2015 r. 
dualna lub grupowa) powinny być dostosowane do potrzeb odbiorcy. Ich katalog nie jest zamknięty, a wyróżnić warto: naukę orientacji przestrzennej i poruszania się, systemu Braille'a, języka migowego lub innych sposobów komunikowania się (szczególnie wspomagających) i alternatywnych metod komunikacji (AAC), spotkania rozwijające umiejętności społeczne. Część zajęć rewalidacyjnych, podobnie jak specjalistycznych z zakresu pomocy psychologiczno-pedagogicznej, ma charakter terapeutyczny. Różnią się tym, że te pierwsze obejmują wyłącznie uczniów z niepełnosprawnością, w związku z czym w ich trakcie stosowane są metody pracy uwzględniające specyficzne potrzeby osób z tej grupy.

Uczniowie zagrożeni niedostosowaniem społecznym mogą skorzystać z zajęć socjoterapeutycznych, a niedostosowani społecznie - z resocjalizacyjnych ${ }^{128}$.

Przedszkola, oddziały przedszkolne w szkołach podstawowych i inne formy wychowania przedszkolnego oraz szkoły, z wyjątkiem szkół artystycznych, zobowiązane są do prowadzenia systematycznych działań w zakresie doradztwa zawodowego. Mają one na celu wspieranie wychowanków w procesie rozpoznawania zainteresowań i predyspozycji oraz podejmowania przez nich świadomych wyborów edukacyjnych i zawodowych ${ }^{129}$. Dla uczniów szkół podstawowych oraz ponadpodstawowych organizuje się zajęcia z zakresu doradztwa zawodowego.

\section{Oferta poradni psychologiczno-pedagogicznych}

Pomoc poradni psychologiczno-pedagogicznych może być pośrednia i bezpośrednia ${ }^{130}$. Ta pierwsza polega na wydaniu dokumentu (orzeczenia, opinii, informacji), który inicjuje proces udzielania wsparcia w przedszkolu, szkole, placówce, do której uczęszcza uczeń. Posiadanie opinii poradni lub orzeczenia wydanego przez zespół orzekający działający w publicznej poradni psychologiczno-pedagogicznej jest często warunkiem niezbędnym do zapewnienia konkretnych form pomocy psychologiczno-pedagogicznej lub dostosowania organizacji kształcenia.

128 Tamże.

129 Art. 26a ustawy Prawo oświatowe oraz Rozporządzenie Ministra Edukacji Narodowej z dnia 12 lutego 2019 r. w sprawie doradztwa zawodowego (Dz.U. poz. 325).

130 Rozporządzenie Ministra Edukacji Narodowej z dnia 1 lutego 2013 r. w sprawie szczegółowych zasad działania publicznych poradni psychologiczno-pedagogicznych, w tym publicznych poradni specjalistycznych (Dz.U. poz. 199 oraz z 2017 r. poz. 1647). 
Pomoc bezpośrednia kierowana jest do dzieci wymagających wsparcia psychologiczno-pedagogicznego lub wsparcia w wyborze kierunku kształcenia i zawodu oraz planowaniu kariery. Poradnie oferują pomoc w różnych formach (katalog jest otwarty): indywidualnej i grupowej terapii dzieci i młodzieży, terapii rodzin, interwencji kryzysowej, grup wsparcia, warsztatów, porad i konsultacji.

\section{Pomoc materialna}

Ważnym instrumentem wsparcia ucznia jest pomoc materialna. Ma ona charakter socjalny (stypendium szkolne, zasiłek szkolny) lub motywacyjny (stypendium za wyniki w nauce lub osiągnięcia sportowe oraz stypendia przyznawane przez Prezesa Rady Ministrów, ministra właściwego do spraw oświaty i wychowania, ministra właściwego do spraw kultury i dziedzictwa narodowego) ${ }^{131}$.

\section{Podsumowanie}

Niniejszy przegląd, mimo że obejmuje jedynie wybrane instrumenty wsparcia, jasno wskazuje, że istnieje wiele możliwości w zakresie tworzenia zindywidualizowanych planów wspierania uczniów o zróżnicowanych potrzebach rozwojowych i edukacyjnych w procesie kształcenia i wychowania. Istotne jest rozwijanie umiejętności nauczycieli i specjalistów oraz kadry zarządzającej placówkami edukacyjnymi, by potrafili je wykorzystywać w sposób, który nie wyłącza uczniów z grupy rówieśniczej, lecz wzmacnia ich zaangażowanie i uczestnictwo oraz pozytywne relacje koleżeńskie. Upowszechnianie wiedzy na temat biopsychospołecznych uwarunkowań potrzeb rozwojowych i edukacyjnych oraz rozwijanie umiejętności jej zastosowania w procesie planowania wsparcia powinno być uwzględnione zarówno w programach studiów przygotowujących do wykonywania zawodu nauczyciela, jak i w odpowiedniej ofercie placówek doskonalenia nauczycieli (Hagiwara i in. 2019, s. 15). Konieczne są również działania, które zapewnią dziecku realny dostęp do pomocy wysokiej jakości w jego najbliższym otoczeniu oraz w jak najkrótszym czasie od momentu rozpoznania takiej potrzeby. 